\title{
Modulation of pesticide response in honeybees
}

\author{
Yannick PoQuet ${ }^{1,2}$, Cyril VIDAu ${ }^{2,3}$, Cédric Alaux ${ }^{1,2,4}$ \\ ${ }^{1}$ INRA, UR 406 Abeilles et Environnement, 228 Route de l'Aérodrome, CS 40509, 84914, Avignon, France \\ ${ }^{2}$ UMT PrADE, CS 40509, 84914, Avignon, France \\ ${ }^{3}$ ITSAP-Institut de l'abeille, 228 Route de l'Aérodrome, Avignon, France \\ ${ }^{4}$ INRA, UR 406 Abeilles et Environnement, Site Agroparc, Domaine Saint-Paul, CS 40509, 84914, Avignon Cedex 9 , \\ France
}

Received 12 June 2015 - Revised 27 November 2015 - Accepted 12 January 2016

\begin{abstract}
Honeybee exposure to pesticides is widely accepted, but the role they play in impacting bee health remains controversial. The development of risk assessment procedures is notably a difficult task due to the variability of responses observed for a single pesticide at a specific dose. Indeed, honeybees, during most of their lifetime, are exposed to fluctuating environmental conditions (e.g., pathogen pressure, resource availability, climatic conditions) and can go through important physiological changes within a few days (e.g., behavioral maturation) or even a day (e.g., circadian clock), which are all factors that can affect the bee response to pesticides. Integrating the range of variability in conditions experienced by bees is relevant to honeybee toxicology and will contribute to a better assessment of their susceptibility to pesticides. The aim of this review is therefore to provide empirical evidence of how co-exposure to stressors, and environmental and endogenous factors modulate the honeybee response to pesticide.
\end{abstract}

Apis mellifera / pesticide toxicity / ecotoxicology / toxicodynamics / toxicokinetics / co-exposure / risk assessment

\section{INTRODUCTION}

Due to their great efficacy, pesticides are used worldwide for plant protection against pests and thus for minimizing the loss of crop yield. However, the production of approximately $75 \%$ of all crop species depends on insect pollination, including by honeybees (Klein et al. 2007). Honeybee colonies, whose development and maintenance are intimately associated with environmental floral resources, can therefore be frequently exposed to multiple pesticide compounds that are recovered in pollen and nectar (Charvet et al. 2004; Mullin et al. 2010; Johnson 2015). Contaminated dust and water can also contribute to increase the risk of exposure (Girolami et al. 2012; Samson-

Corresponding author: C. Alaux, cedric.alaux@avignon.inra.fr Manuscript editor: Yves Le Conte
Robert et al. 2014). While foraging, bees can be exposed to some pesticides, but acute exposure can become chronic after frequent foraging trips. In addition, pesticides and corresponding metabolites are brought back to the hive and stored in several matrices, like honey, wax, and bee bread, thereby exposing all members of the colony to these compounds. The large number of bees in a colony combined with their wide-ranging foraging (generally up to $10 \mathrm{~km}$ (Beekman and Ratnieks 2000; Steffan-Dewenter and Kuhn 2003)) together increase the potential for centralizing environmental toxicants in a hive. Miticides originating from beekeeping practices, as well as veterinary drugs (e.g., farm uses), can also contribute to the composition of the xenobiotic complex. Such level of exposure has been confirmed by numerous studies using residue analysis of bees and hive matrices (for examples, see Bogdanov 2006; Chauzat et al. 2009; Mullin et al. 2010; Lambert et al. 2013; Ravoet et al. 2015). 
Reflecting this frequent exposure to pesticides, bee toxicology has become a fast-growing field of research for characterizing the detrimental effects of pesticides on bee health, as well as the underlying mechanisms (Desneux et al. 2007; van der Sluijs et al. 2013; Godfray et al. 2014; Johnson 2015). The large body of literature that has accumulated shows that the toxicant effects depend on the type, dose, mode, and frequency of exposure (Belzunces et al. 2012; Godfray et al. 2014; Johnson 2015) but, most importantly, that the effect of a given pesticide can be modulated by several endogenous and/or exogenous factors (Le Conte et al. 2011). Indeed, owing to the diversity of methods used by researchers, the complex nature of pesticide toxicity is being revealed. At a given dose, pesticides do not induce one rigid effect but a range of responses that can vary in intensity depending on others factors. Such a modulation of response might not be surprising given that phenotypic responses (e.g., morphology, development, and behavior) are commonly regulated by endogenous (genotype, physiology) and exogenous factors (environment). Ultimately, a comprehensive view of this response variability will be required for better understanding the phenomenon of colony decline and to develop a more detailed pesticide risk assessment in bees.

In this review, we describe two relevant scenarios affecting the modulation of pesticide response in honey bees: first, the co-occurrence of pesticides with other stressors, and second, the role of environmental and physiological variability (Figure 1). We then review the experimental evidence for such modulation and, finally, propose directions for future research in the field of bee toxicology.

\section{SCENARIOS OF BEE RESPONSE TO PESTICIDE}

\subsection{Pesticide effect}

The effects of xenobiotics (e.g., pesticides) on organisms classically depend on two main factors: toxicokinetics and toxicodynamics. Toxicokinetics refers to the fate of the molecule in the body of the organism and involves different mechanisms: its uptake, distribution, biotransformation, and elimination. Toxicodynamics correspond to the interaction between the toxic compound, and the target, and its action and effect on the organism (e.g., physiological impairment, mortality). How an organism will deal with the toxicant (toxicokinetics) and how the toxicant will affect the organism (toxicodynamics) will depend on the physiological background of the organism.

There is little information on the toxicokinetics of pesticides in honeybees. However, the detoxification system involved in toxicokinetics is gaining greater attention in recent toxicological studies (Berenbaum and Johnson 2015). This physiological system reduces the number of toxic molecules before they reach the target and/or after being removed from the target. Detoxification generally reduces the toxicity of xenobiotics if all metabolites are less active than the original molecule, but that is not always the case (e.g., conversion of imidacloprid to the more toxic metabolite olefin (Suchail et al. 2001)). This process involves enzymes that degrade xenobiotics and membrane transporters that facilitate their elimination. Generally, there are three types of enzymes: enzymes located on the membranes of the endoplasmic reticulum that catalyze oxidation, reduction, and hydrolysis reactions (e.g., carboxyl/cholinesterase (CE) and cytochrome P450 monooxygenases (CYP450)), transfer enzymes localized in the cytosol that catalyze conjugation reactions (e.g., glutathione S-transferases (GST)), and transmembrane enzymes that use adenosine triphosphate (ATP) to transport diverse substrates (peptides, toxins, lipids, and hydrophobic molecules) across the cell membrane (e.g., ATP-binding cassette transporters) (Claudianos et al. 2006; Berenbaum and Johnson 2015).

Enzymes from the detoxification system are known to have other functions related to cell signaling, dietary detoxification, hormone and pheromone metabolism, and neurodevelopment (Oakeshott et al. 2005; Claudianos et al. 2006; Laborde 2010). Changes in the detoxification system (toxicokinetics) are therefore expected throughout bee development or as the adult bee ages, which would suggest that pesticide response can be modulated depending on bee physiology. However, we cannot exclude an interplay with other physiological mechanisms: For instance, a 


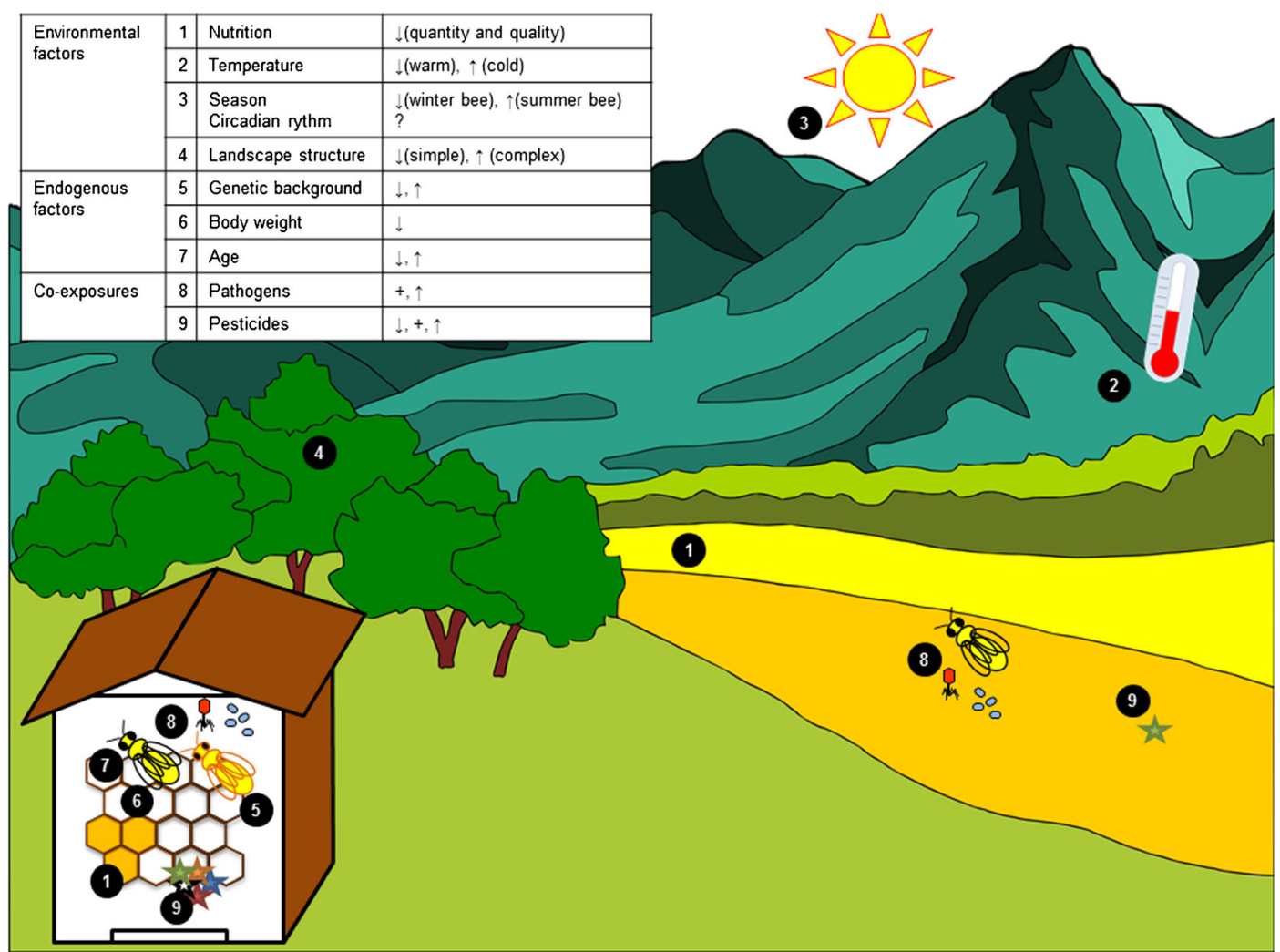

Figure 1. Factors involved in the modulation of pesticide response. Downwards arrow and upwards arrow indicate a decrease and increase in pesticide toxicity, respectively, and plus sign denotes an additive effect. Question mark means that the effect on pesticide toxicity is unknown.

toxicant might interfere with a specific physiological function at the time of exposure (e.g., energy storage, metabolism, thermoregulation) (Belzunces et al. 2012; Derecka et al. 2013) rendering the individual more or less responsive to the toxicant (toxicodynamics).

\subsection{Co-exposure to stressors}

As described previously, honeybee colonies can be co-exposed to a complex web of pesticides and corresponding metabolites. In addition, honeybees represent a very attractive and valuable resource for pathogens due to the high concentration of individuals and stored food in the colony (Schmid-Hempel 1998). As a result, colonies are often infested by numerous pathogens covering several kingdoms, the most common being viruses, bacteria, fungi, and mites (Evans and Schwarz
2011; Nazzi and Pennacchio 2014; Runckel et al. 2011). Therefore, due to their social lifestyle and biology, honeybees can concentrate pesticides and pathogens in a single spot (hive) and thus are forced to cope with frequent co-exposure to stressors (pesticide/pesticide or pesticide/pathogen) (Chauzat et al. 2009; van Engelsdorp et al. 2009; Mullin et al. 2010; Cornman et al. 2012; Ravoet et al. 2013; Simon-Delso et al. 2014).

The pesticide response can be modified in several ways depending on the type of co-exposure: The response corresponds to the sum of expected individual responses (additive effects) or is different from the expected response (interactive effects). Two types of interactive effects can occur: synergism and antagonism, referring to greater or smaller effects than expected from the single exposure, respectively (Holmstrup et al. 2010). Classically, synergism is observed (i) when two 
stressors interact in a way that generally enhance the effect of each other or (ii) when a nonharmful stressor enhances the harmfulness of another one, or when two nonharmful stressors induce harmful effects (potentiation). Antagonism occurs when the combination of two stressors decreases the response induced by a single one. However, while those interactive effects can be easily tested and classified, interpreting the underlying mechanisms requires knowing the mode of action of each stressor. Interaction between pesticides can occur at the pharmacological target sites and/or at the detoxification level, notably via competition. For example, detoxification of each toxicant can be undermined because certain mechanisms are required at the same time and toward several molecules (competitive inhibition). Pathogens can alter the physiology and metabolism of the host, impacting several important life-history traits (e.g., longevity and development) and modifying functions involved in pesticide toxicokinetics and toxicodynamics such as the detoxification system, as shown with Varroa mite and Nosema Microsporidia parasitism (Vidau et al. 2011; Dussaubat et al. 2012; Gregorc et al. 2012; Di Pasquale et al. 2013; Aufauvre et al. 2014). As for pesticides, there is evidence that toxicants can reduce immunocompetence of bees (Boncristiani et al. 2012; Di Prisco et al. 2013; Aufauvre et al. 2014) and energetic metabolism (Derecka et al. 2013), functions that are required to fight pathogens. Such data clearly show a great potential for interactive effects between pesticide and pathogens.

\subsection{Variability of environmental and endogenous factors}

Numerous studies have shown the incredible plasticity of endocrine and neurochemical functions of bees. For example, workers exhibit many changes in endocrine activity, metabolism, neural functioning, and circadian clock activity when shifting from nursing to foraging activity (Robinson 2002). This includes changes in body weight with foragers who can weigh half as much as nurses (Vance et al. 2009). Physiological changes can also be attributed to genotypic (Robinson 2002), seasonal (Castillo et al. 2012), and resource variation (Brodschneider and Crailsheim 2010). Whether the functions involved in pesticide toxicokinetics and toxicodynamics respond to this variability or can be altered by social, environmental, or genotypic conditions has not received much consideration. However, recent results indicate that pollen intake affects the level of CYP450 transcripts (Alaux et al. 2011; Corby-Harris et al. 2014) and that the activity of GST varies according to the quality of the ingested pollen (Di Pasquale et al. 2013). The expression level of genes coding for CYP450 enzymes can also oscillate with circadian rhythms but with a different phase between nurses and foragers (Rodriguez-Zas et al. 2012). In addition, foragers have been shown to exhibit a higher GST activity than nurses (Smirle and Robinson 1989). Differential expression in the type and level of target receptors also occurs (Jones et al. 2006), which potentially impacts pesticide toxicodynamics. Finally, a proteomic study revealed that the majority of detoxification enzymes are expressed at about the same level in the three castes (queen, drone, and worker) (Chan et al. 2013). However, queens exhibit a higher expression of the multidrug-resistant proteins as compared to drones and workers, and the enzymes belonging to the CYP450 family are significantly more highly expressed in workers than in queens and drones. Altogether, these results point to the fact that the bee response to a given pesticide will change as a function of its environment and proper physiological state.

\section{MODULATION OF PESTICIDE RESPONSE BY CO-EXPOSURE TO OTHER STRESS FACTORS}

\subsection{Interaction between pathogens and pesticides}

Epidemiologic surveys conducted around the world have shown that honeybee colonies may host numerous pathogens. Their presence could be pathogenic, but most of the colonies overcome infestation and remain asymptomatic. Similarly, low doses of pesticides generally do not affect the survival of bees, but the same exposure can become lethal if bees are also exposed to 
pathogens. For example, Vidau et al. (2011) tested the effects of sublethal exposure of the systemic insecticides thiacloprid and fipronil on bees experimentally infected by Nosema ceranae. The authors found that thiacloprid and fipronil exposures decrease the survival of Nosema-infected bees (synergistic interaction), whereas pesticide exposure alone had no effect. Comparable experimental settings using combinations of Nosema and pesticide exposure have reproduced this phenomenon (Aufauvre et al. 2012; Doublet et al. 2015). More importantly, it appears that this synergistic interaction is not specific to Nosema but ubiquitous, as it has been reported for intoxicated bees infected with the Black Queen Cell Virus (Doublet et al. 2015) or challenged with lipopolysaccharides from the bacteria Escherichia coli (Kohler et al. 2012). A decrease in the cypermethrin $\mathrm{LD}_{50}$ by a factor of 2.66 was also found in emerging bees infected with the chronic bee paralysis virus (Bendahou et al. 1997).

However, it seems that synergistic interactions between pathogens and pesticides are not highly reproducible and/or are dependent on others factors (environmental and endogenous factors, see below). For example, Aufauvre et al. (2014) did not find a synergistic interaction between Nosema and fipronil despite using a similar procedure to Vidau et al. (2011). This was likely due to a seasonal effect since experiments were performed in September (France) with a possible effect of Varroa destructor (Aufauvre et al. 2014). Exposure to Nosema and thiacloprid at the colony level did not produce the synergistic interaction (Retschnig et al. 2015) observed in laboratory conditions (Vidau et al. 2011; Retschnig et al. 2014). It is likely that the colony environment has a buffering effect on stress exposure and/or that control bees die faster in their natural environment than in laboratory conditions leading to no effect of treatments (Alaux et al. 2014). In addition, the type of interaction between pathogens and pesticides may be dose-dependent. For example, by exposing Nosema-infected bees to different concentrations of imidacloprid $(0.7,7$, and $70 \mu \mathrm{g} / \mathrm{kg}$ ), Alaux et al. (2010) reported additive effects on the mortality at the lowest and medium concentrations but synergistic effects at the highest concentration. Similar results were obtained with bees parasitized by Nosema and exposed to thiacloprid ( 35 and $70 \mathrm{mg} /$ ); only the highest concentration led to a synergistic interaction affecting bee survival (Retschnig et al. 2014).

Another factor modulating pesticide response may be the type of pesticide applied. For example, recent work on bumble bees (Bombus terrestris) has shown exacerbated impacts of a combined exposure to the trypanosome parasite Crithidia bombi and neonicotinoid insecticides (clothianidin and thiamethoxam) (Fauser-Misslin et al. 2014), but similar effects were not observed when $B$. terrestris was exposed to C. bombi infection coupled with exposure to a pyrethroid pesticide (lambda-cyhalothrin) (Baron et al. 2014). The effect of this latter combination was no worse for these bumblebees than exposure to pyrethroid alone.

Mechanisms underlying these pathogen/ pesticide interactions are unknown but a recent transcriptomic study showed that the level of expression of some genes is affected only in bees coexposed to fipronil and Nosema (e.g., genes coding for cuticular related proteins and trehalose transporter) (Aufauvre et al. 2014). A decrease in glucose oxidase activity was also observed in bees exposed to the combination Nosema/ imidacloprid, whereas the parasite and pesticide alone did not affect this enzymatic activity (Alaux et al. 2010). In the case of synergism, it is not clear yet whether the pesticide promotes the pathogenicity of the pathogen or, conversely, the pathogen increases the toxicity of the pesticide. Indeed, synergism occurs whether bees are exposed sequentially or simultaneously to the parasite and the pesticide (Aufauvre et al. 2012). However, pesticides can promote the replication of pathogens in the host, as observed with $N$. ceranae (Pettis et al. 2012; Wu et al. 2012) and some viruses (Black Queen Cell Virus and deformed wing virus) (DeGrandi-Hoffman et al. 2013; Di Prisco et al. 2013). Di Prisco et al. (2013) showed that the abrupt increase in viral loads was due to a reduction in immune activity by the pesticide; this response was specific to the neonicotinoid clothianidin and not observed with the organophosphate chlorpyriphos. Those latter results also suggest that pesticides have the potential to increase the probability of co-exposures within the 
colony, and therefore, asymptomatic infection could become symptomatic (potentiation effect). Nevertheless, it seems that apart from the pathogenicity of the foreign agent, the cost of an immune response also affects the response to sublethal doses of pesticide. Indeed, the combined challenge of nonpathogenic immune-activators (lipopolysaccharides) and a toxicant triggers synergistic effect on bee survival (Kohler et al. 2012).

\subsection{Interaction between pesticides}

Pesticide response in organisms can be influenced by previous or concomitant exposure to other chemicals. This is also true for honeybees (Thompson 2012; Johnson 2015). By far the majority of studies have reported synergistic interactions involving the inhibition of insecticide-metabolizing enzymes; such is the case of piperonyl butoxyde (PBO), one of the most commonly registered synergists used in plant protection formulations to enhance insecticide efficiency. In honeybees, this compound inhibits CYP450s and increases the toxicity of a wild range of insecticides, especially pyrethroids, organophosphates, carbamates, and neonicotinoids. However, depending on the relative importance of CYP450 activity in insecticide degradation, the scale of the increase in toxicity may differ widely, even within the same chemical family. As an example, Iwasa et al. (2004) showed that bee exposure to PBO increases the toxicity of acetamiprid and thiacloprid 6- and 154-fold, respectively, whereas toxicity of imidacloprid is unaffected. Similarly, toxicity of acaricides is modified in bees previously exposed to PBO as shown for coumaphos, fenpyroximate, and tau-fluvalinate (980-fold), but not for amitraz (Johnson et al. 2006; Johnson et al. 2013). Inhibitors of GST (diethyl maleate) and CE $(S, S, S$-tributyl phosphorotrithioate) can also modulate toxicity of insecticides and acaricides but to a lesser extent than PBO (Iwasa et al. 2004; Johnson et al. 2013).

Modulation of insecticide toxicity by fungicides has long been known (Pilling 1992), and that is why the use of some mixtures of active ingredients for protecting crops is regulated in some country. In particular, ergosterol biosynthesis-inhibiting (EBI) fungicides can modify the toxicity of pyrethroid insecticides. As an example, prochloraz, tebuconazole, flusilazole, and difenoconazole elevate the mortality rate of bees exposed to deltamethrin, alpha-cypermethrin, or lambda-cyhalothrin (Belzunces and Colin 1993; Pilling and Jepson 1993; Thompson and Wilkins 2003). In addition, the toxicity of the acaricides tau-fluvalinate and flumethrin (pyrethroid) can be enhanced by prochloraz and flusilazole, respectively (Thompson 2012). Data from Pilling et al. (1995) indicates that the mechanism underlying these interactions is an inhibition of CYP450 activity by EBI fungicides, slowing detoxification of pyrethroid in bees. However, an effect of the combination of EBI-fungicide and pyrethroids on bees thermoregulation cannot be excluded (Vandame and Belzunces 1998). Likewise, a synergistic effect of EBI fungicides occurs with some neonicotinoids as indicated by the 244- and 1141-fold increase in toxicity of acetamiprid and thiacloprid, respectively, in bees previously exposed to triflumizole (Iwasa et al. 2004). Finally, non-EBI fungicides may also influence the bee response to insecticide, but the underlying mechanisms have not yet been investigated (Schmuck et al. 2003; Thompson and Wilkins 2003).

In some cases, bees can be exposed to two pesticides that are both substrates of the same metabolizing enzymes. This has the potential to modify the pesticide toxicity as suggested by the synergistic interaction between the acaricides taufluvalinate and coumaphos (Johnson et al. 2009; Johnson et al. 2013), both metabolized by CYP9Q enzymes (Mao et al. 2011). A modulation of pesticide response can also occur independently of action on the detoxification system. For example, the mitochondrial inhibitors pyraclostrobin and boscalid used as fungicides increase the toxicity of tau-fluvalinate and fenpyroximate (Johnson et al. 2013), and some antibiotics affect the susceptibility of bees to coumaphos and taufluvalinate via an inhibition of efflux transporter (Hawthorne and Dively 2011).

\section{MODULATION OF PESTICIDE RESPONSE BY THE ENVIRONMENT}

Due to their perennial life cycle and generalistfeeding regime, honeybee colonies can experience major changes in climatic conditions and 
nutrient intake, which provides additional sources of variability in the bee's response to pesticides. Indeed, it is well-established that resource quantity and/or quality provide specific nutrients that modulate stress resistance in insects (Simpson et al. 2015). As an example, young African bees (A. mellifera scutellata) provided with a proteinrich diet better withstand a dual stress (temperature and nicotine exposure) than individuals fed a poor-protein diet (Archer et al. 2014). More specifically, a protective role of honey and pollen against xenobiotic exposures has been revealed. One study reported that in young bees (8-9 days old), pesticide resistance increased with the amount and quality of pollen (protein rate) (Wahl and Ulm 1983). It was later found that pollen intake actually stimulates the expression of several genes encoding detoxification enzymes, which might be linked to an increase of the survival rate of bees exposed to pesticides (Alaux et al. 2011; Corby-Harris et al. 2014; Schmehl et al. 2014). The compound $p$-coumaric acid, a ubiquitous component of the pollen, was described as an upregulator of all classes of detoxification genes (Mao et al. 2013). Differences in protective effects between pollen types might also be due to diverse levels of detoxification enzymes. Indeed, Di Pasquale et al. (2013) found that bees fed with Erica pollen developed a higher GST activity in the head than control bees (fed no pollen), but Castanea pollen failed in promoting a higher GST activity. In addition, honey and nectar contain compounds that exert a positive effect on bee detoxification capacity (Mao et al. 2011; Johnson et al. 2012; Mao et al. 2013). Ethyl acetate and methanol subfractions of honey modulate the transcription of CYP9Q2 and CYP9Q3, belonging to the CYP450 gene subfamily (Mao et al. 2011). It also appears that quercetin, a natural component of plant nectar, administered through the food, increases the median lethal dose $\left(\mathrm{LD}_{50}\right)$ of taufluvalinate (Johnson et al. 2012). Therefore, those studies concluded that diets of sugar, often provided as honey substitute by beekeepers, might compromise bee capacities to cope with pesticides. Altogether, these results suggest that pesticide toxicokinetics might change according to availability of floral resources and thus the season.
Because honeybees are ectotherms, their body temperature and many of their biological functions are dependent on the environmental temperature. Several studies have shown that the response to pesticides is actually temperature dependant. In laboratory conditions, worker bees are less sensitive to some pesticides when the temperature increases (Ladas 1972). As an example, when exposed to dichlorodiphenyltrichloroethane (DDT), bees maintained at $27^{\circ} \mathrm{C}$ tended to present a higher $\mathrm{LD}_{50}$ than bees kept at $21^{\circ} \mathrm{C}$ (Graves and Mackensen 1965). A similar trend was found in the other castes (queen and drone). It was also found that a decrease in the brood rearing temperature from 35 to $33{ }^{\circ} \mathrm{C}$ modifies the susceptibility of larvae (higher $\mathrm{LD}_{50}$ ) but also emerging adults to dimethoate (higher susceptibility) (Medrzycki et al. 2010), highlighting the potential long-term effect of thermal conditions on pesticide sensitivity. Metabolic rate, and therefore, flight activity are also tightly linked to the ambient temperature (Harrison and Fewell 2002; Woyke et al. 2003). A field experiment demonstrated that below $28^{\circ} \mathrm{C}$, thiamethoxam significantly decreased the homing rate, but effects were minor above this temperature (Henry et al. 2014).

Temporal variations in pesticide response have been observed with significant differences from season to season. Indeed, greater pesticide sensitivity has been observed in summer bees compared to winter bees (Wahl and Ulm 1983; Smirle and Winston 1987; Decourtye et al. 2003). The synergy that exists between prochloraz and deltamethrin was reported in summer bees but not in winter bees (Meled et al. 1998). The lower sensitivity to pesticides of winter bees seems to be a general phenomenon and might be linked to their unique physiology of long-lived bees as compared to summer bees, but whether they have an enhanced detoxification system is not known. Temporal variation in pesticide sensitivity could also occur within a day as suggested by the circadian oscillation in CYP450 gene expression of nurses and foragers (Rodriguez-Zas et al. 2012) that might lead to chronotoxicity, as found in the fruit fly Drosophila melanogaster (Hooven et al. 2009). Time of the day might then be a factor to consider regarding pesticide exposure. 
Finally, because most of the pesticides targeting insect pests in agroecosystems are neurotoxicants, impairment of brain functions involved in learning and memory has been observed after sublethal exposure (Belzunces et al. 2012; Palmer et al. 2013). However, pesticide-induced impairment can vary depending on the complexity of the cognitive task; studies by Henry et al. $(2012,2014)$ showed that in bees exposed to thiamethoxam, part of the variation in homing failure was due to previous experience in the landscape and its structure. Forager bees use path integration and landmarks to navigate and collect food in their environment (Collett and Collett 2002), and thus, it was more difficult for intoxicated bees to perform homing flight in a challenging landscape (Henry et al. 2012, 2014). Navigation failure was later confirmed within a simplified landscape: Bees treated with neonicotinoids (imidacloprid, clothianidin, and thiacloprid) failed to use landmarks for returning to their colony when released in an unfamiliar site (Fischer et al. 2014).

\section{MODULATION OF PESTICIDE RESPONSE BY ENDOGENOUS FACTORS}

In honeybees, the queen mates with many males creating genetic diversity (multiple patrilines) within the colony. This contributes to the production of bees which exhibit different sensitivities to social and environmental conditions (Robinson and Page 1989). One would thus expect that bees from different patrilines differ in their pesticide sensitivity or detoxification capacities, but this remains to be investigated. However, several studies indicate that the genetic background might influence the response to pesticides, given that the toxicity of a chemical varies between bees originating from different subspecies (Ladas 1972; Suchail et al. 2000; Laurino et al. 2013; Sandrock et al. 2014; Rinkevich et al. 2015) or colonies from the same strain (Tahori et al. 1969; Smirle and Winston 1987). Indeed, one CYP450 gene was found to vary in expression between colonies originating from a hybrid population (A. m. mellifera/carnica) (Derecka et al. 2013). This topic requires dedicated experiments because the expression of genes, biological functions, and thus phenotypic response is also largely dependent on environmental conditions (see above).

In toxicology, the effect of a dose is often related to the body weight of the organism; it is therefore recommended to express the dose of exposure as the ratio of chemical weight by individual body weight. For example, in bumblebees, which exhibit large differences in body size and weight within a colony, smaller individuals tend to have a lower $\mathrm{LD}_{50}$ than larger individuals (Thompson and Hunt 1999). Within honeybee colonies, differences in body size between workers are very minor, but nurses are heavier than foragers and a large variability in body weight is observed between nurse bees as compared to foragers (Vance et al. 2009). Accordingly, it was found that heavier bees are less sensitive to toxicants than lighter bees (Tahori et al. 1969; Gerig 1975; Nogueira-Couto et al. 1996).

Bees exhibit tremendous physiological changes when aging and switching behavioral functions. It is therefore not surprising to observe age-dependent response to toxicants. For example, young bees were found to be more sensitive to some toxicants but less to others as compared to older bees (Mayland and Burkardt 1970; Ladas 1972; Bendahou et al. 1997; Rinkevich et al. 2015). Wahl and Ulm (1983) found an agerelated increase in sensitivity to an herbicide and fungicide, as well as a higher level of Nosema spore loads in old bees. In this particular case, age and parasitic loads seemed to be confounded where the higher sensitivity of older bees might simply be a consequence of Nosema and pesticide co-exposure. More surprising was the contrasting effect of a pesticide (imidacloprid) on a cognitive task (habituation of the proboscis extension reflex) between bees of 1 day of difference (7- vs 8 -day-old bees) (Guez et al. 2001). In a follow-up of their study, the authors suggested that this effect is associated to toxicodynamics factors with a differential expression of two subtypes of nicotinic acetylcholine receptors during the bee behavioral maturation (Guez et al. 2003). A significant change occurring within such a short timewindow was further confirmed by the work of Whitfield et al. (2006), who found that during 
behavioral maturation, young bees exhibit massive change in brain gene expression and those changes are essentially completed by 8 days of age.

Finally, despite clear physiological differences between the three castes (queen, drone, worker), few studies investigated their differential susceptibly to pesticides. By adjusting the body weight difference and comparing the $\mathrm{LD}_{50}$ values of queen and workers exposed to widely used acaricides, Dahlgren et al. (2012) found that queens were more tolerant than workers to four (tau-fluvalinate, fenpyroximate, thymol, and coumaphos) of the five tested acaricides; no difference was found for amitraz. Similarly, a higher $\mathrm{LD}_{50}$ to DDT was previously found for queens as compared to workers (Graves and Mackensen 1965). The underlying mechanisms have yet to be elucidated, but differences might arise from a caste-specific toxicokinetics of pesticides, because queens have different expression profiles of CYP450 family proteins and multidrugresistant proteins than workers (Chan et al. 2013). Both types of proteins are involved in pesticide resistance in insects (Buss et al. 2002; Srinivas et al. 2004; Li et al. 2007). Not mutually exclusive is the hypothesis that queens and workers exhibit different pesticide toxicodynamics as suggested by the higher tolerance of queens to the oxidative stress generated by a xenobiotic (Corona et al. 2007). Since the glycoprotein vitellogenin has a protective role against oxidative stress (Seehuus et al. 2006) and is expressed at a higher level in queens compared to workers (Corona et al. 2007) and winter bees compared to summer bees (Fluri et al. 1982), it is reasonable to assume that the greater tolerance to toxicants of queens and winter bees is mediated by this protein.

\section{CONCLUSIONS AND PERSPECTIVES}

The major recent finding in honeybee toxicology is that pesticides may interact with other stress factors and that their toxic effects are modulated by the environment or the physiological background of individuals (Figure 1). The body of evidence is growing and clearly shows that pesticide response in honeybees is variable. However, the amount of data is still limited, and thus, much remains to be investigated in this particular domain of bee toxicology. Studying the modulation of pesticide responses by other factors will be a crucial step to understand the bee responses observed in the field, notably whether and how exposure below the $\mathrm{LD}_{50}$ can cause high bee mortality.

Pesticide co-exposure with other toxicants or pathogens in honeybees seems to be a common phenomenon. This web of exposure combined with high genetic variability within (patrilines) or between colonies (subspecies, ecotype) and a range of physiological states and environmental conditions experienced by bees opens many potential avenues for the modification of pesticide toxicity. Determining whether and in what way pesticide toxicokinetics and toxicodynamics are influenced by these factors is essential for predicting the honey bee response to pesticides. However, since bee exposure to some of these factors is age- or task-related, one needs to take into account the exposure relevance before developing such studies (Figure 2). For example, nurse bees are constantly exposed to hive matrices and might be more prone to cocktail effects than foragers in the case of colony contamination, but foragers might experience higher rates of pathogen/pesticide co-exposure than nurse bees due to the risk of infection accumulated through their life.

The risk assessment of pesticide toxicity is generally based on laboratory assays performed under optimal conditions for the bees (e.g., temperature and ad libitum nutrients). Such assays enable the isolation of the pesticide effect on specific biological parameters (e.g., behavior, development, and mortality). However, in their natural environment, honeybees rarely face such optimal conditions but are exposed to a large variability of environmental conditions from suboptimal to severe. For example, bees reared under optimal conditions in the laboratory clearly live longer than bees reared in colonies in the field (Alaux et al. 2014). The observed effects of potential stressors (parasitism and immune stimulation) on bee longevity under natural conditions are also reduced (parasitism) or not detected (immune stimulation) compared to laboratory conditions which is likely due to the fact that control bees 


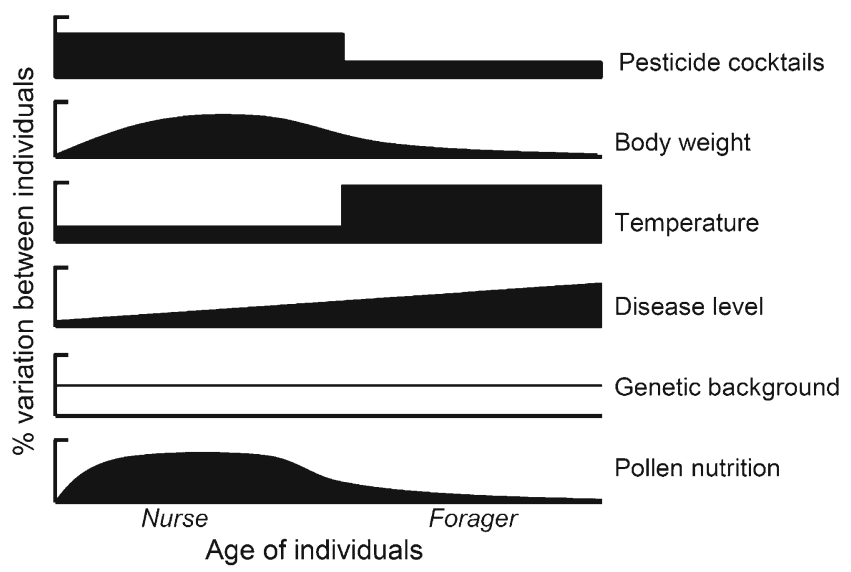

Figure 2. Age- or task-related variability of factors that can modulate pesticide response.

have a reduced longevity in nonoptimal field conditions (Alaux et al. 2014). It is therefore recommended to perform pesticide bioassays under a range of test conditions that reflect the range of variability in conditions experienced by bees in the field (Holmstrup et al. 2010). Standardization of pesticide assays is necessary for comparing results between laboratories and countries, but it should not overshadow the need to test a range of conditions for risk assessment.

Due to the large number of factors that can modulate individual response to pesticides, a great variability of responses is also expected at the colony level. In bumblebees, some studies have advanced into the investigation of the consequences of pesticide/pathogens or pesticide/pesticide combinations at the colony level (Gill et al. 2012; Baron et al. 2014; Fauser-Misslin et al. 2014). Testing such combinations of exposures in honeybee colonies is more complex when compared to the small-size and annual life cycle of bumblebee colonies. However, recent progress in modeling honeybee colony response to stress factors could solve a part of this problem (Bryden et al. 2013; Khoury et al. 2013; Becher et al. 2014; Perry et al. 2015). Efforts should then be made to supply models with accurate data on the diverse factors that can modulate pesticide response (e.g., genetic, pathogen, nutrition), which will reduce uncertainty factors in these models. Finally, in field toxicological surveys monitoring colony decline, some factors may be more relevant than others in shaping the colony response to toxicants. Indeed, within an apiary, colonies are exposed to the same microclimate, landscape, and environmental resources. The way each colony exploits its environment will determine its level of exposition to pesticides, but with similar exposure, genetic and disease backgrounds of the colony will be key contributors of the variability in the colony response.

\section{ACKNOWLEDGMENTS}

Y. Poquet was supported by the MACIF Foundation and Terre d'Abeilles (No. 201110). We would like to thank C.M. McDonnell for help with the English editing and the referees for comments that greatly improved the manuscript.

Modulation de la réponse aux pesticides chez les abeilles

Apis mellifera / toxicité des pesticides / écotoxicologie / toxicocinétique / toxicodynamique / co-exposition / évaluation des risques

Modulation bei der Reaktion gegenüber Pestiziden bei Honigbienen

Apis mellifera / Pestizidtoxizität / Ökotoxikologie / Toxikodynamik / Toxikokinetik / Risikoabschätzung

\section{REFERENCES}

Alaux, C., Brunet, J.L., Dussaubat, C., Mondet, F., Tchamitchan, S., Cousin, M., Brillard, J., Baldy, A., Belzunces, L.P., Le Conte, Y. (2010) Interactions 
between Nosema microspores and a neonicotinoid weaken honeybees (Apis mellifera). Environ. Microbiol. 12, 774-782

Alaux, C., Dantec, C., Parrinello, H., Le Conte, Y. (2011) Nutrigenomics in honey bees: digital gene expression analysis of pollen's nutritive effects on healthy and varroa-parasitized bees. BMC Genomics 12, 496

Alaux, C., Crauser, D., Pioz, M., Saulnier, C., Le Conte, Y. (2014) Parasitic and immune modulation of flight activity in honey bees tracked with optical counters. J. Exp. Biol. 217, 3416-3424

Archer, C.R., Pirk, C.W.W., Wright, G.A., Nicolson, S.W. (2014) Nutrition affects survival in African honeybees exposed to interacting stressors. Funct. Ecol. 28, 913-923

Aufauvre, J., Biron, D.G., Vidau, C., Fontbonne, R., Roudel, M., Diogon, M., Vigues, B., Belzunces, L.P., Delbac, F., Blot, N. (2012) Parasite-insecticide interactions: a case study of Nosema ceranae and fipronil synergy on honeybee. Sci. Rep. 2, 326

Aufauvre, J., Misme-Aucouturier, B., Vigues, B., Texier, C., Delbac, F., Blot, N. (2014) Transcriptome analyses of the honeybee response to Nosema ceranae and insecticides. Plos One 9, e91686

Baron, G.L., Raine, N.E., Brown, M.J.F. (2014) Impact of chronic exposure to a pyrethroid pesticide on bumblebees and interactions with a trypanosome parasite. J. Appl. Ecol. 51 , 460-469

Becher, M.A., Grimm, V., Thorbek, P., Horn, J., Kennedy, P.J., Osborne, J.L. (2014) BEEHAVE: a systems model of honeybee colony dynamics and foraging to explore multifactorial causes of colony failure. J. Appl. Ecol. 51, 470-482

Beekman, M., Ratnieks, F.L.W. (2000) Long-range foraging by the honey-bee, Apis mellifera L. Funct. Ecol. 14, 490-496

Belzunces, L., Colin, M.E. (1993) Synergies between insecticides and fungicides applied to honey bees at sublethal doses. Phytoma 446, 20-24

Belzunces, L.P., Tchamitchian, S., Brunet, J.L. (2012) Neural effects of insecticides in the honey bee. Apidologie 43, 348-370

Bendahou, N., Bounias, M., Fleche, C. (1997) Acute toxicity of cypermethrin and fenitrothion on honeybees (Apis mellifera mellifera) according to age, formulations and (chronic paralysis virus)/insecticide interaction. J. Environ. Biol. 18, 55-65

Berenbaum, M.R., Johnson, R.M. (2015) Xenobiotic detoxification pathways in honeybees. Curr. Opin. Insect Sci. . doi:10.1016/j.cois.2015.03.005

Bogdanov, S. (2006) Contaminants of bee products. Apidologie 37, 1-18

Boncristiani, H., Underwood, R., Schwarz, R., Evans, J.D., Pettis, J., vanEngelsdorp, D. (2012) Direct effect of acaricides on pathogen loads and gene expression levels in honey bees Apis mellifera. J. Insect Physiol. 58, 613-620

Brodschneider, R., Crailsheim, K. (2010) Nutrition and health in honey bees. Apidologie 41, 278-294
Bryden, J., Gill, R.J., Mitton, R.A.A., Raine, N.E., Jansen, V.A.A. (2013) Chronic sublethal stress causes bee colony failure. Ecol. Lett. 16, 1463-1469

Buss, D.S., McCaffery, A.R., Callaghan, A. (2002) Evidence for $\mathrm{p}$-glycoprotein modification of insecticide toxicity in mosquitoes of the Culex pipiens complex. Med. Vet. Entomol. 16, 218-222

Castillo, C., Maisonnasse, A., Conte, Y.L., Plettner, E. (2012) Seasonal variation in the titers and biosynthesis of the primer pheromone ethyl oleate in honey bees. J. Insect Physiol. 58, 1112-1121

Chan, Q.W.T., Chan, M.Y., Logan, M., Fang, Y., Higo, H., Foster, L.J. (2013) Honey bee protein atlas at organlevel resolution. Genome Res. 23, 1951-1960

Charvet, R., Katouzian-Safadi, M., Colin, M.E., Marchand, P.A., Bonmatin, J.M. (2004) Systemic insecticides: new risk for pollinator insects. Ann. Pharm. Fr. 62, 29-35

Chauzat, M.P., Carpentier, P., Martel, A.C., Bougeard, S., Cougoule, N., Porta, P., Lachaize, J., Madec, F., Aubert, M., Faucon, J.P. (2009) Influence of pesticide residues on honey bee (Hymenoptera: Apidae) colony health in France. Environ. Entomol. 38, 514-523

Claudianos, C., Ranson, H., Johnson, R.M., Biswas, S., Schuler, M.A., Berenbaum, M.R., Feyereisen, R., Oakeshott, J.G. (2006) A deficit of detoxification enzymes: pesticide sensitivity and environmental response in the honeybee. Insect Mol. Biol. 15, 615-636

Collett, T.S., Collett, M. (2002) Memory use in insect visual navigation. Nat. Rev. Neurosci. 3, 542-552

Corby-Harris, V., Jones, B.M., Walton, A., Schwan, M.R., Anderson, K.E. (2014) Transcriptional markers of suboptimal nutrition in developing Apis mellifera nurse workers. BMC Genomics 15, 134

Cornman, R.S., Tarpy, D.R., Chen, Y.P., Jeffreys, L., Lopez, D., Pettis, J.S., vanEngelsdorp, D., Evans, D. (2012) Pathogen webs in collapsing honey bee colonies. Plos One 7, e43562

Corona, M., Velarde, R.A., Remolina, S., Moran-Lauter, A., Wang, Y., Hughes, K.A., Robinson, G.E. (2007) Vitellogenin, juvenile hormone, insulin signaling, and queen honey bee longevity. Proc. Natl. Acad. Sci. U. S. A. 104, 7128-7133

Dahlgren, L., Johnson, R.M., Siegfried, B.D., Ellis, M.D. (2012) Comparative toxicity of acaricides to honey bee (Hymenoptera: Apidae) workers and queens. J. Econ. Entomol. 105, 1895-1902

Decourtye, A., Lacassie, E., Pham-Delegue, M.H. (2003) Learning performances of honeybees (Apis mellifera L) are differentially affected by imidacloprid according to the season. Pest Manag. Sci. 59, 269-278

DeGrandi-Hoffman, G., Chen, Y., Simonds, R. (2013) The effects of pesticides on queen rearing and virus titers in honey bees (Apis mellifera L.). Insects 4, 71-89

Derecka, K., Blythe, M.J., Malla, S., Genereux, D.P., Guffanti, A., et al. (2013) Transient exposure to low levels of insecticide affects metabolic networks of honeybee larvae. Plos One 8, e68191 
Desneux, N., Decourtye, A., Delpuech, J.M. (2007) The sublethal effects of pesticides on beneficial arthropods. Annu. Rev. Entomol. 52, 81-106

Di Pasquale, G., Salignon, M., Le Conte, Y., Belzunces, L.P., Decourtye, A., Kretzschmar, A., Suchail, S., Brunet, J.-L., Alaux, C. (2013) Influence of pollen nutrition on honey bee health: do pollen quality and diversity matter? Plos One 8, e72016

Di Prisco, G., Cavaliere, V., Annoscia, D., Varricchio, P., Caprio, E., Nazzi, F., Gargiulo, G., Pennacchio, F. (2013) Neonicotinoid clothianidin adversely affects insect immunity and promotes replication of a viral pathogen in honey bees. Proc. Natl. Acad. Sci. U. S. A. 110, 18466-18471

Doublet, V., Labarussias, M., de Miranda, J.R., Moritz, R.F.A., Paxton, R.J. (2015) Bees under stress: sublethal doses of a neonicotinoid pesticide and pathogens interact to elevate honey bee mortality across the life cycle. Environ. Microbiol. Rep. 17, 969-983

Dussaubat, C., Brunet, J.L., Higes, M., Colbourne, J.K., Lopez, J., et al. (2012) Gut pathology and responses to the Microsporidium Nosema ceranae in the honey bee Apis mellifera. Plos One 7, e37017

Evans, J.D., Schwarz, R.S. (2011) Bees brought to their knees: microbes affecting honey bee health. Trends Microbiol. 19, 614-620

Fauser-Misslin, A., Sadd, B., Neumann, P., Sandrock, C. (2014) Influence of combined pesticide and parasite exposure on bumblebee colony traits in the laboratory. J. Appl. Ecol. 51 , 450-459

Fischer, J., Muller, T., Spatz, A.K., Greggers, U., Grunewald, B., Menzel, R. (2014) Neonicotinoids interfere with specific components of navigation in honeybees. Plos One 9, e91364

Fluri, P., Luscher, M., Wille, H., Gerig, L. (1982) Changes in weight of pharyngeal gland and haemolymph titres of juvenile hormone, protein and vitellogenin in worker honey bees. J. Insect Physiol. 28, 61-68

Gerig, L. (1975) The effects of juvenile hormone analogues on summer bees (Apis mellifera L.) in the field and laboratory. Schweiz. Landwirtsch. Forsch. 14, 355370

Gill, R.J., Ramos-Rodriguez, O., Raine, N.E. (2012) Combined pesticide exposure severely affects individualand colony-level traits in bees. Nature 491, 105-108

Girolami, V., Marzaro, M., Vivan, L., Mazzon, L., Greatti, M., Giorio, C., Marton, D., Tapparo, A. (2012) Fatal powdering of bees in flight with particulates of neonicotinoids seed coating and humidity implication. J. Appl. Entomol. 136, 17-26

Godfray, H.C.J., Blacquiere, T., Field, L.M., Hails, R.S., Petrokofsky, G., Potts, S.G., Raine, N.E., Vanbergen, A.J., McLean, A.R. (2014) A restatement of the natural science evidence base concerning neonicotinoid insecticides and insect pollinators. Proc. R. Soc. B 281, 20140558

Graves, J.B., Mackensen, O. (1965) Topical application and insecticide resistance studies on the honey bee. J. Econ. Entomol. 58, 990-993
Gregorc, A., Evans, J.D., Scharf, M., Ellis, J.D. (2012) Gene expression in honey bee (Apis mellifera) larvae exposed to pesticides and Varroa mites (Varroa destructor ). J. Insect Physiol. 58, 1042-1049

Guez, D., Suchail, S., Gauthier, M., Maleszka, R., Belzunces, L.P. (2001) Contrasting effects of imidacloprid on habituation in 7- and 8-day-old honeybees (Apis mellifera). Neurobiol. Learn. Mem. 76, 183-191

Guez, D., Belzunces, L.P., Maleszka, R. (2003) Effects of imidacloprid metabolites on habituation in honeybees suggest the existence of two subtypes of nicotinic receptors differentially expressed during adult development. Pharmacol. Biochem. Behav. 75, 217-222

Harrison, J.F., Fewell, J.H. (2002) Environmental and genetic influences on flight metabolic rate in the honey bee, Apis mellifera . Comp. Biochem. Physiol. A 133, 323-333

Hawthorne, D.J., Dively, G.P. (2011) Killing them with kindness? In-hive medications may inhibit xenobiotic efflux transporters and endanger honey bees. Plos One 6, e26796

Henry, M., Beguin, M., Requier, F., Rollin, O., Odoux, J.F., Aupinel, P., Aptel, J., Tchamitchian, S., Decourtye, A. (2012) A common pesticide decreases foraging success and survival in honey bees. Science 336, 348-350

Henry, M., Bertrand, C., Le Féon, V., Requier, F., Odoux, J.-F., Aupinel, P., Bretagnolle, V., Decourtye, A. (2014) Pesticide risk assessment in free-ranging bees is weather and landscape dependent. Nat. Commun. 5, 4359

Holmstrup, M., Bindesbol, A.M., Oostingh, G.J., Duschl, A., Scheil, V., et al. (2010) Interactions between effects of environmental chemicals and natural stressors: a review. Sci. Total Environ. 408, 3746-3762

Hooven, L.A., Sherman, K.A., Butcher, S., Giebultowicz, J.M. (2009) Does the clock make the poison? Circadian variation in response to pesticides. Plos One 4 , e6469

Iwasa, T., Motoyama, N., Ambrose, J.T., Roe, R.M. (2004) Mechanism for the differential toxicity of neonicotinoid insecticides in the honey bee, Apis mellifera . Crop. Prot. 23, 371-378

Johnson, R.M. (2015) Honey bee toxicology. Annu. Rev. Entomol. 60, 415-434

Johnson, R.M., Wen, Z., Schuler, M.A., Berenbaum, M.R. (2006) Mediation of pyrethroid insecticide toxicity to honey bees (Hymenoptera: Apidae) by cytochrome P450 monooxygenases. J. Econ. Entomol. 99, 1046-1050

Johnson, R.M., Pollock, H.S., Berenbaum, M.R. (2009) Synergistic interactions between in-hive miticides in Apis mellifera. J. Econ. Entomol. 102, 474-479

Johnson, R.M., Mao, W.F., Pollock, H.S., Niu, G.D., Schuler, M.A., Berenbaum, M.R. (2012) Ecologically appropriate xenobiotics induce cytochrome P450s in Apis mellifera. Plos One 7, e31051

Johnson, R.M., Dahlgren, L., Siegfried, B.D., Ellis, M.D. (2013) Acaricide, fungicide and drug interactions in honey bees (Apis mellifera). Plos One 8, e54092 
Jones, A.K., Raymond-Delpech, V., Thany, S.H., Gauthier, M., Sattelle, D.B. (2006) The nicotinic acetylcholine receptor gene family of the honey bee, Apis mellifera . Genome Res. 16, 1422-1430

Khoury, D.S., Barron, A.B., Myerscough, M.R. (2013) Modelling food and population dynamics in honey bee colonies. Plos One 8, e59084

Klein, A.M., Vaissiere, B.E., Cane, J.H., Steffan-Dewenter, I., Cunningham, S.A., Kremen, C., Tscharntke, T. (2007) Importance of pollinators in changing landscapes for world crops. Proc. R. Soc. B 274, 303-313

Kohler, A., Pirk, C.W.W., Nicolson, S.W. (2012) Simultaneous stressors: interactive effects of an immune challenge and dietary toxin can be detrimental to honeybees. J. Insect Physiol. 58, 918-923

Laborde, E. (2010) Glutathione transferases as mediators of signaling pathways involved in cell proliferation and cell death. Cell Death Differ. 17, 1373-1380

Ladas, A. (1972) The influence of some internal and external factors upon the insecticide resistance of honeybee. Apidologie 3, 55-78

Lambert, O., Piroux, M., Puyo, S., Thorin, C., L'Hostis, M., Wiest, L., Bulete, A., Delbac, F., Pouliquen, H. (2013) Widespread occurrence of chemical residues in beehive matrices from apiaries located in different landscapes of Western France. Plos One 8, e67007

Laurino, D., Manino, A., Patetta, A., Porporato, M. (2013) Toxicity of neonicotinoid insecticides on different honey bee genotypes. Bull. Insectol. 66, 119-126

Le Conte, Y., Brunet, J.-L., McDonnell, C., Dussaubat, C., Alaux, C. (2011). Interactions between risk factors in honey bees. In: Sammataro, D., Yoder, J. (eds) Honey Bee Colony Health: Challenges and Sustainable Solutions, Taylor \& Francis Inc, pp. 215-222

Li, X., Schuler, M.A., Berenbaum, M.R. (2007) Molecular mechanisms of metabolic resistance to synthetic and natural xenobiotics. Annu. Rev. Entomol. 52, 231-253

Mao, W.F., Schuler, M.A., Berenbaum, M.R. (2011) CYP9Q-mediated detoxification of acaricides in the honey bee (Apis mellifera). Proc. Natl. Acad. Sci. U. S. A. 108, 12657-12662

Mao, W., Schuler, M.A., Berenbaum, M.R. (2013) Honey constituents up-regulate detoxification and immunity genes in the western honey bee Apis mellifera. Proc. Natl. Acad. Sci. U. S. A. 110, 8842-8846

Mayland, P.G., Burkardt, C.C. (1970) Honey bee mortality as related to insecticide-treated surfaces and bee age. J. Econ. Entomol. 63 , 1438-1439

Medrzycki, P., Sgolastra, F., Bortolotti, L., Bogo, G., Tosi, S., Padovani, E., Porrini, C., Sabatini, A.G. (2010) Influence of brood rearing temperature on honey bee development and susceptibility to poisoning by pesticides. J. Apic. Res. 49, 52-59

Meled, M., Thrasyvoulou, A., Belzunces, L.P. (1998) Seasonal variations in susceptibility of Apis mellifera to the synergistic action of prochloraz and deltamethrin. Environ. Toxicol. Chem. 17, 2517-2520
Mullin, C.A., Frazier, M., Frazier, J.L., Ashcraft, S., Simonds, R., van Engelsdorp, D., Pettis, J.S. (2010) High levels of miticides and agrochemicals in North American apiaries: Amplications for honey bee health. Plos One 5, e9754

Nazzi, F., Pennacchio, F. (2014) Disentangling multiple interactions in the hive ecosystem. Trends Parasitol. 30, 556-561

Nogueira-Couto, R.H., Abe, C.S., Pitelli, R.A. (1996) Efeito do paraquat na mortalidade de operárias de Apis mellifera (abelhas africanizadas). Naturalia 21, 49-55

Oakeshott, J.G., Claudianos, C., Campbell, P.M., Newcomb, R.D., Russell, R.J. (2005) Biochemical genetics and genomics of insect esterases. In: Gilbert, L.I., Iatrou, K., Gill, S.S. (eds.) Comprehensive molecular insect science-pharmacology, pp. 309-381. Elsevier, Oxford

Palmer, M.J., Moffat, C., Saranzewa, N., Harvey, J., Wright, G.A., Connolly, C.N. (2013) Cholinergic pesticides cause mushroom body neuronal inactivation in honeybees. Nat. Commun. 4, 1634

Perry, C.J., Sovik, E., Myerscough, M.R., Barron, A.B. (2015) Rapid behavioral maturation accelerates failure of stressed honey bee colonies. Proc. Natl. Acad. Sci. U. S. A. 112, 3427-3432

Pettis, J.S., Van Engelsdorp, D., Johnson, J., Dively, G. (2012) Pesticide exposure in honey bees results in increased levels of the gut pathogen Nosema. Naturwissenschaften 99, 153-158

Pilling, E.D. (1992) Evidence for pesticide synergism is the honeybee (Apis mellifera ). Asp. Appl. Biol. 31 , 43-47

Pilling, E.D., Jepson, P.C. (1993) Synergism between EBI fungicides and A pyrethroid insecticide in the honeybee (Apis mellifera). Pestic. Sci. 39, 293-297

Pilling, E.D., Bromley-Challenor, K.A.C., Walker, C.H., Jepson, P.C. (1995) Mechanism of synergism between the pyrethroid insecticide $\lambda$-cyhalothrin and the imidazole fungicide orochloraz, in the honeybee (Apis mellifera L.). Pestic. Biochem. Physiol. 51, 1-11

Ravoet, J., Maharramov, J., Meeus, I., De Smet, L., Wenseleers, T., Smagghe, G., de Graaf, D.C. (2013) Comprehensive bee pathogen screening in belgium reveals Crithidia mellificae as a new contributory factor to winter mortality. Plos One 8, e72443

Ravoet, J., Reybroeck, W., de Graaf, D.C. (2015) Pesticides for apicultural and/or agricultural application found in Belgian honey bee wax combs. Bull. Environ Contam. Toxicol. 94, 543-548

Retschnig, G., Neumann, P., Williams, G.R. (2014) Thiacloprid-Nosema ceranae interactions in honey bees: host survivorship but not parasite reproduction is dependent on pesticide dose. J. Invertebr. Pathol. 118, 18-19

Retschnig, G., Williams, G.R., Odemer, R., Boltin, J., Di Poto, C., Mehmann, M.M., Retschnig, P., Winiger, P., Rozenkranz, P., Neumann, P. (2015) Effects, but no interactions, of ubiquitous pesticide and parasite stressors on honey bee (Apis mellifera) lifespan and behaviour in a colony environment. Environ. Microbiol. doi:10.1111/1462-2920.12825 
Rinkevich, F.D., Margotta, J.W., Pittman, J.M., Danka, R.G., Tarver, M.R., Ottea, J.A., Healy, K.B. (2015) Genetics, synergists, and age affect insecticide sensitivity of the honey bee, Apis mellifera. Plos One $\mathbf{1 0}$, $\mathrm{e} 0139841$

Robinson, G.E. (2002) Genomics and integrative analyses of division of labor in honeybee colonies. Am. Nat. $160, \mathrm{~S} 160-\mathrm{S} 172$

Robinson, G.E., Page, R.E. (1989) Genetic basis for division of labor in an insect society. In: Breed, D., Page, R.E. (eds.) The genetics of social evolution, pp. 61-81. West View Press, Boulder

Rodriguez-Zas, S.L., Southey, B.R., Shemesh, Y., Rubin, E.B., Cohen, M., Robinson, G.E., Bloch, G. (2012) Microarray analysis of natural socially regulated plasticity in circadian rhythms of honey bees. J. Biol. Rhythms 27, 12-24

Runckel, C., Flenniken, M.L., Engel, J.C., Ruby, J.G., Ganem, D., Andino, R., DeRisi, J.L. (2011) Temporal analysis of the honey bee microbiome reveals four novel viruses and seasonal prevalence of known viruses, Nosema, and Crithidia. Plos One 6, e20656

Samson-Robert, O., Labrie, G., Chagnon, M., Fournier, V. (2014) Neonicotinoid-contaminated puddles of water represent a risk of intoxication for honey bees. Plos One 9, e108443

Sandrock, C., Tanadini, M., Tanadini, L.G., Fauser-Misslin, A., Potts, S.G., Neumann, P. (2014) Impact of chronic neonicotinoid exposure on honeybee colony performance and queen supersedure. Plos One 9, e103592

Schmehl, D.R., Teal, P.E.A., Frazier, J.L., Grozinger, C.M. (2014) Genomic analysis of the interaction between pesticide exposure and nutrition in honey bees (Apis mellifera ). J. Insect Physiol. 71, 177-190

Schmid-Hempel, P. (1998) Parasites in social insects. Princeton University Press, Princeton

Schmuck, R., Stadler, T., Schmidt, H.W. (2003) Field relevance of a synergistic effect observed in the laboratory between an EBI fungicide and a chloronicotinyl insecticide in the honeybee (Apis mellifera L, Hymenoptera). Pest Manag. Sci. 59, 279-286

Seehuus, S.C., Norberg, K., Gimsa, U., Krekling, T., Amdam, G.V. (2006) Reproductive protein protects functionally sterile honey bee workers from oxidative stress. Proc. Natl. Acad. Sci. U. S. A. 103, 962-967

Simon-Delso, N., San Martin, G., Bruneau, E., Minsart, L. A., Mouret, C. \& Hautier, L. (2014) Honeybee colony disorder in crop areas: the role of pesticides and viruses. doi:10.1371/journal.pone.0103073

Simpson, S.J., Clissold, F.J., Lihoreau, M., Ponton, F., Wilder, S.M., Raubenheimer, D. (2015) Recent advances in the integrative nutrition of arthropods. Annu. Rev. Entomol. 60, 293-311

Smirle, M.J., Robinson, G.E. (1989) Behavioral status and detoxifying enzyme-activity are related in worker honey bees. J. Insect Behav. 2, 285-289

Smirle, M.J., Winston, M.L. (1987) Intercolony variation in pesticide detoxification by the honey-bee (Hymenoptera, Apidae). J. Econ. Entomol. 80, 5-8
Srinivas, R., Udikeri, S.S., Jayalakshmi, S.K., Sreeramulu, K. (2004) Identification of factors responsible for insecticide resistance in Helicoverpa armigera. Comp. Biochem. Physiol. C 137, 261-269

Steffan-Dewenter, I., Kuhn, A. (2003) Honeybee foraging in differentially structured landscapes. Proc. R. Soc. B. 270, 569-575

Suchail, S., Guez, D., Belzunces, L.P. (2000) Characteristics of imidacloprid toxicity in two Apis mellifera subspecies. Environ. Toxicol. Chem. 19, 1901-1905

Suchail, S., Guez, D., Belzunces, L.P. (2001) Discrepancy between acute and chronic toxicity induced by imidacloprid and its metabolites in Apis mellifera. Environ. Toxicol. Chem. 20, 2482-2486

Tahori, A.S., Sobel, Z., Soller, M. (1969) Variability in insecticide tolerance of eighteen honey bee colonies. Entomol. Exp. App. 12, 85-98

Thompson, H. M. (2012). Interaction between pesticides and other factors in effects on bees. EFSA, pp. 204

Thompson, H.M., Hunt, L.V. (1999) Extrapolating from honeybees to bumblebees in pesticide risk assessment. Ecotoxicology 8, 147-166

Thompson, H.M., Wilkins, S. (2003) Assessment of the synergy and repellency of pyrethroid/fungicide mixtures. Bull. Insectol. 56, 131-134

van der Sluijs, J.P., Simon-Delso, N., Goulson, D., Maxim, L., Bonmatin, J.M., Belzunces, L.P. (2013) Neonicotinoids, bee disorders and the sustainability of pollinator services. Curr. Opin. Environ. Sustain. 5, 293-305

van Engelsdorp, D., Evans, J.D., Saegerman, C., Mullin, C., Haubruge, E., et al. (2009) Colony collapse disorder: A descriptive study. Plos One 4, e6481

Vance, J.T., Williams, J.B., Elekonich, M.M., Roberts, S.P. (2009) The effects of age and behavioral development on honey bee (Apis mellifera) flight performance. J. Exp. Biol. 212, 2604-2611

Vandame, R., Belzunces, L.P. (1998) Joint actions of deltamethrin and azole fungicides on honey bee thermoregulation. Neurosci. Lett. 251, 57-60

Vidau, C., Diogon, M., Aufauvre, J., Fontbonne, R., Viguès, B., Brunet, J.-L., Texier, C., Biron, D.G., Blott, N., El Alaoui, H., Belzunces, L.P. (2011) Exposure to sublethal doses of fipronil and thiacloprid highly increases mortality of honeybees previously infected by Nosema ceranae. Plos One 6, e21550

Wahl, O., Ulm, K. (1983) Influence of pollen feeding and physiological condition on pesticide sensitivity of the honey bee Apis mellifera carnica . Oecologia 59, 106128

Whitfield, C.W., Ben-Shahar, Y., Brillet, C., Leoncini, I., Crauser, D., Le Conte, Y., Rodriguez-Zas, S., Robinson, G.E. (2006) Genomic dissection of behavioral maturation in the honey bee. Proc. Natl. Acad. Sci. U. S. A. 103, 16068-16075

Woyke, J., Wilde, J., Wilde, M. (2003) Flight activity reaction to temperature changes in Apis dorsata, Apis laboriosa and Apis mellifera. J. Apic. Sci. 47, 73-80 
Wu, J.Y., Smart, M.D., Anelli, C.M., Sheppard, W.S. (2012) Honey bees (Apis mellifera) reared in brood combs containing high levels of pesticide residues exhibit increased susceptibility to Nosema (Microsporidia) infection. J. Invertebr. Pathol. 109, 326-329 